\title{
3 Research Soure \\ High Food Insecurity in Recyclers from Waste Sorting Units in Southern Brazil
}

Cássia Medino Soares ( $\nabla$ cassia.medino.cs@gmail.com )

Universidade Federal do Rio Grande do Sul https://orcid.org/0000-0003-0112-4673

Camila Saueressig

Universidade Federal do Rio Grande do Sul

\section{Bruna Alves}

Universidade Federal do Rio Grande do Sul

\section{Carolina Bortolin Beskow}

Universidade Federal do Rio Grande do Sul

Paulo Roberto Taborda de Souza Filho

Universidade Federal de Ciencias da Saude de Porto Alegre

Dvora Joveleviths

Hospital de Clinicas de Porto Alegre

Valesca Dall'Alba

Universidade Federal do Rio Grande do Sul

\section{Research article}

Keywords: Food security, Social vulnerability, Waste management, substance abuse

Posted Date: July 9th, 2019

DOI: https://doi.org/10.21203/rs.2.11101/v1

License: (9) This work is licensed under a Creative Commons Attribution 4.0 International License.

Read Full License 


\section{Abstract}

Background In areas of greater social vulnerability, there are high levels of food insecurity, infectious diseases and diseases secondary to malnutrition. However, in Brazil, there are few studies with recyclers from waste sorting units, resulting in a lack of health promotion programs for this population. This study aimed to describe the prevalence of food insecurity in recyclers from waste sorting units in the south of Brazil. Methods Cross-sectional study conducted from May of 2017 to April of 2018 with adult individuals from two waste sorting units in the city of Porto Alegre, southern Brazil. Clinical and nutritional evaluations were performed in the work environment, and three questionnaires were applied: the Brazilian Scale of Food Insecurity, the Alcohol, Smoking and Substance Involvement Screening Test, and the International Questionnaire of Physical Activity. Results One hundred and twenty-three subjects were evaluated, mean age 35 years, $66 \%$ female. A $74 \%$ rate of food insecurity was detected. About $57 \%$ of the participants presented overweight or obesity and $48 \%$ presented increased waist circumference. Conclusion Subjects presented high levels of Food Insecurity and immediate need of intervention for tobacco and alcohol abuse. There is a need for multidisciplinary interventions to prevent the situations found and the implementation of public policies addressing health promotion acts in the population of recyclers.

\section{Abstract}

Background: In areas of greater social vulnerability, there are high levels of food insecurity, infectious diseases and diseases secondary to malnutrition. However, in Brazil, there are few studies with recyclers from waste sorting units, resulting in a lack of health promotion programs for this population. This study aimed to describe the prevalence of food insecurity in recyclers from waste sorting units in the south of Brazil.

Methods: Cross-sectional study conducted from May of 2017 to April of 2018 with adult individuals from two waste sorting units in the city of Porto Alegre, southern Brazil. Clinical and nutritional evaluations were performed in the work environment, and three questionnaires were applied: the Brazilian Scale of Food Insecurity, the Alcohol, Smoking and Substance Involvement Screening Test, and the International Questionnaire of Physical Activity.

Results: One hundred and twenty-three subjects were evaluated, mean age 35 years, $66 \%$ female. A $74 \%$ rate of food insecurity was detected. About $57 \%$ of the participants presented overweight or obesity and $48 \%$ presented increased waist circumference.

Conclusion: Subjects presented high levels of Food Insecurity and immediate need of intervention for tobacco and alcohol abuse. There is a need for multidisciplinary interventions to prevent the situations found and the implementation of public policies addressing health promotion acts in the population of recyclers.

Key words: Food security, Social vulnerability, Waste management, substance abuse. 


\section{Background}

Food security is defined as a state when "all people, at all times, have physical, social and economic access to sufficient, sage and nutritious food that meets their dietary needs and food preferences for an active and healthy life" [1]. It is a multidimensional phenomenon which is characterized by lack of access to sufficient amount of nutritious food and it is a known risk factor for malnutrition in children and the development of cardiovascular diseases in adults [2-3]. It is categorized by two indicators: one based on the adequacy of food consumption, and the other based on the severity of the restriction on food access [4].

Food security is a necessity in order to guarantee nutrition security. However, it is known that vulnerable populations in least developed countries are permeated with a number of inequalities that lead to food insecurity. Recently, a number of social phenomena such as the global economic crisis and rising levels of unemployment have been linked to rising food insecurity in least developed countries [5]. Studies also shows that the lack of access to primary health care and basic education are important risk factors that lead to food insecurity. It is known that all of these variables result not only in the reduction of food consumption but also in reduction of quality and food diversity [6].

The lack of calories and nutrients is linked to the development of a number of health issues and diseases, leading to an unhealthy and less productive (economic wise) society [7]. In socially vulnerable regions where the income is insufficient to ensure quality foods, there are higher rates of food and nutritional insecurity, contagious diseases, infections, chronic diseases, and diseases that are secondary to malnutrition $[8,9]$.

Food Insecurity is correlated with a combination of multiple factors that may lead to the decline of the standard of well-being of people, families, or communities, depending on the exposure to given types of risks. In workplaces with unhealthy conditions, located in areas where income is often less than a minimum wage, with limited access to food and low level of schooling, quality of life may be impaired $[10,11,12]$.

A significant number of people live on sorting and recycling waste throughout Latin America. This occurs partly because of the great fragility of the economy of these countries, where many people do not have another source of income [13]. In Brazil currently, approximately 76 million tons of garbage are thrown out daily, but only $3 \%$ are recycled $[14,15]$.

Health care assistance at Waste Sorting Units (WSU) does not obey a specific public policy, which means that it is difficult for health care teams to access these environments. Mostly, waste pickers work due to financial need, without a contract or access to health services, showing traits similar to other groups of people excluded from society, and are exposed to health risks and all sorts of socio economic problems $[16,17,18,19]$. 
The most recent study on food insecurity among Brazilians, the Brazilian National Household Sample Survey, identified that $30.2 \%$ of the population from all regions suffered from food insecurity. Brazil's northeast region has the highest degree of Food Insecurity when compared to others, being $44.2 \%$ of Food Insecurity [20].

There is a lack of studies in Brazil with people that work at waste sorting units, such as recyclers and waste pickers. There are clinical and health studies (none of them about food security per se) performed with brazilian street sweepers, but the working conditions of the latter are very different from those of the pickers (in Brazil street sweepers are documented workers whereas waste pickers work in the informal sector) [19]. The objective of this study was to describe the health profile of recyclers from two Waste Sorting Units in the South of Brazil, in terms of nutritional profile, prevalence of food insecurity, rates of physical activity and substance usage.

\section{Methods}

Study sites and participants

A prospective cross-sectional study was performed in the city of Porto Alegre, South of Brazil, from May of 2017 to April of 2018. The municipality has a total of 17 sorting units. The total number of members varies from unit to unit, considering the high level of turnover, which is characteristic of this type of work because of the prevalence of informal ties to work. It is estimated according to the city's health department, that about 700 people work at these seventeen units [21]. Data were collected at two WSUs in Porto Alegre, because of the prior insertion of the researchers into these places. All other units were approached and contacted, but declined to participate or failed to reply. Both WSUs have been active since the end of the 1990s sharing similar characteristics on the selective recycling of solid wastes.

The study population included pickers associated from these Waste Sorting Units, men and women over the age of 18 years, who accepted to participate in the study and signed the Letter of Free Informed Consent. The convenience sample was composed of 123 people out of the total of 150 members of both WSUs.

\section{Data collection, variables and measurements}

Initially, an educational approach was performed with the pickers for sensitization regarding the objectives of this study. Later, the dates were set for data collection and assessments. Meetings were held at the associations with an individual approach made by a multidisciplinary team composed of twelve multidisciplinary health professionals (nutritionists, physicians, nurses, nursing technicians, pharmacists, biochemists and a psychologist).

Questionnaires were applied to evaluate Food Insecurity, Physical Activity and Substance Usage. All of the scales and questionnaires were applied by researchers with prior experience of using the instruments. The Brazilian Scale of Food Insecurity (EBIA- Escala Brasileira de Insegurança Alimentar) was used to 
assess food security. It was previously adapted and validated for the Brazilian population [22]. It measures the difficulty of family access to food, and the psycholog ical and social dimensions of food insecurity. The scale is easy to apply and low-cost. It is composed of 15 questions (and their occurrence frequency, totalizing in 30 items) referring to the ninety-day period before the day of the interview. The scores of the 30 questions are classified at four levels: Food security, mild food insecurity, moderate food insecurity and severe food insecurity [22].

The International Physical Activity Questionnaire (IPAQ) was used and applied to evaluate the time spent weekly on physical exercise. IPAQ is an instrument developed to estimate the level of habitual practice of physical activity among populations of different countries and cultural contexts. Because of time constraints it was decided to use the short form of the questionnaire consisting of eight open-ended questions which allow estimating the time spent per week on different types of physical activity: walking - vigorous or moderate, physical effort and physical inactivity - seated position.For this study the results were classified as: sedentary and active [23].

The Alcohol, Smoking and Substance Involvement Screening Test (ASSIST) questionnaire was used to assess substance usage. It's consisted of eight objective questions to detect usage and frequency of psychoactive substances. ASSIST supplies information about substances that have already been used in lifetime, substances used in the last three months, problems resulting from substance usage, current and future risks, as well as the use of injectable drugs. At the end, scores for each substance identify the need or not for interventions, for problematic usage of psychoactive substances [24].

Body weight and stature of the individuals were obtained using the Welmy® Adult Electronic Professional Scale with Anthropometric Ruler W 200/100 A. The Waist Circumference (WC) was measured between the margin of the last rib and the iliac crest with a flexible, non-elastic fiberglass tape. The classification of BMI (Body Mass Index) for adults up to 60 years of age followed the parameters recommended by the World Health Organization (WHO) [25] and for the elderly the cutoff points proposed by Lipschitz were used, where the individuals are classified as being undernourished if the BMI is less than $22 \mathrm{~kg} / \mathrm{m}^{2}$, eutrophic with a BMI between 22 and $27 \mathrm{~kg} / \mathrm{m}^{2}$ and overweight if the BMI is greater than $27 \mathrm{~kg} / \mathrm{m}^{2}$. WC was classified according to the specific cutoff points for Brazilian adults: $\geq 92 \mathrm{~cm}$ for men and $\geq 86 \mathrm{~cm}$ for women [26].

Data analyses

Data analysis was performed using SPSS ® V.20 (Statistical Package for the Social Sciences).

Descriptive statistics were carried out for frequencies and percentiles of all variables measured. The Kolmogorov-Smirnov Test was used to evaluate normality distribution of the variables. A Spearman correlation test was performed to verify the association between variables and a Mann-Whitney test to compare the medians between independent samples.

Ethical considerations 
The Health Ethics Committee for Hospital de Clínicas de Porto Alegre (HCPA) linked to the Ministry of Health and Ministry of Education, (No. 2.162.481) approved the study protocol and materials. A written informed consent was obtained from all participants. They were also informed that they could decline or withdraw from the study at any time.

\section{Results}

One hundred and twenty-three (123) associates out of a total of 150 from two sorting units participated in the study. Most of the subjects consisted of women with a low level of schooling (below $4^{\text {th }}$ grade), overweight and/or obese. Seventy-three (73) percent of the individuals presented some type of food insecurity according to EBIA, and among those that presented insecurity, 54.8\% $(n=49)$ had children, which means a worsening of insecurity. The frequencies of the responses for the EBIA questionnaire are shown in Table 1. (Manuscript Table 1 in the Supplementary Files)

The questionnaire's results and characteristics of the population studied are described in Table 2. (Manuscript Table 2 in the Supplementary Files)

Spearman correlation analyses indicated that subjects who had less years of schooling presented a higher prevalence of food insecurity $(\rho=-0.24 ; p<0.01)$.

Mann-Whitney analysis was conducted to compare the medians among the groups. Results suggested that women had greater waist circumference compared to the men $(p<0.05)$. Moreover, the $\mathrm{BMI}$ indices were greater among people who needed intervention for Alcohol abuse $(p<0.05)$.

\section{Discussion}

In this study, $73 \%$ of the population presented Food Insecurity. This prevalence found among pickers is more than the double than the national index and more than the triple than the southern regional index (figure 1). [20] According to the Brazilian National Household Sample Survey, food insecurity was higher in the North $(36.1 \%)$ and Northeast (38.1\%) regions, as well as in the rural area (35.3\%). Food insecurity was found in $28.8 \%$ of households where lived underaged people [20]. Among pickers living with children, the percentage found was twice as the national index.

In a study with a vulnerable population from the northeast part of Brazil, it was identified that $88.8 \%$ of rural householders suffered from food insecurity ( $15.1 \%$ suffered from severe form of food insecurity) [27]. Among waste pickers, $16.2 \%$ presented severe food insecurity, which is alarming since it's higher than rural households (that already live under socioeconomical vulnerable conditions) and considering that these workers reside in one of the largest capitals and urban areas of Brazil.

According to the United States Department of Agriculture (USDA), a survey found prevalence indices of $12.3 \%$ of food insecurity in all American homes and 31.6\% in homes of single mothers with children [28]. 
Food insecurity is more prevalent in Latin America than in the United States. In 2015 the rates found in Latin America were between $12.7 \%$ and $32.8 \%$ among households living below the poverty line $[29,30]$.

Food insecurity was found in $81 \%$ of 794 low-income families that had children in Ecuador [31] and in $76 \%$ of the 7187 households in Mexico [31]; In a study involving families with children in Quebec, Canada and Jamaica, a prevalence of food insecurity was found to be $9 \%$ and $26 \%$, respectively [32]. Food Insecurity rates found among the population working in Waste Sorting Units are similar to those found in regions of extreme poverty in different countries. This association may be related to poor working conditions, since they don't have labor rights and work under extreme poor conditions linked to the informal economy. Recyclers perform essential and indispensable work considering Brazil's current condition as a least developed country, but do not receive enough safe food, much needed to exercise the workforce in their labor, which leads them to consume foods of poor nutritional quality in insufficient quality and quantities

Regarding their demographic profile, results of the present study showed that over half the population of recyclers consisted of women, self-declared black and with incomplete basic schooling. High indices of excessive weight was also found. According to the National Survey of the Ministry of Health and Demography the main indicators of Food Insecurity refer to race and sex, with a prevalence in the profile of self-declared black women [33,34]. Besides these characteristics, regional aspects, age group, per capita income and domiciliary status are related to the severity of food insecurity [35]. Many people in Brazil living in highly vulnerable situations survive by eating remnants that were discarted by other families, without access to any kind of good quality food and in sufficient quantity. Social exclusion, followed by the lack of job opportunities, causes various types of damages. These problems are indirectly observed in the increased rates of infectious diseases, in initial stages of child development, in increased rate of crime and substance abuse $[19,36]$.

There are a series of factors that could explain how obesity could be associated with food insecurity, among them, the lack of access to healthy foods, large quantities of low nutritional quality foods and lack of diversification of foods that, consequently, lead to the bad quality of the eating routine [36,37]. A significant prevalence of overweight and obesity was found among the recyclers evaluated. Studies have shown that obesity is more frequent in socially less favored population groups, independent of being classified by level of education, social class or some other variable of socioeconomic level $[38,39,40]$. It is known that excessive weight and obesity are directly related to food quality, to intake of foods with high glycemic index and to low nutritional quality [38]. Recyclers don't have breaks at work to consume quality meals, mainly because they earn proportionally to the amount they recycle: when they have a break, they choose foods that can be eaten quickly, usually with very low nutritional quality, such as instant noodles and other types of junk food [39]. Besides, part of this population eats what they find among the waste while they are sorting it, which denotes concern with satiating their hunger to be able to work, not with nutritional quality [39]. 
Further, regarding the BMI, according to the Brazilian Institute of Geography and Statistics the prevalence of overweight estimated for all Brazilian women aged from 15 to 49 years, was $43 \%$, ranging from $45.1 \%$ in the Center-West region to $19.4 \%$ in the South. As to the accumulation of abdominal fat, the women of the evaluated units presented a greater waist circumference compared to the men, with a greater risk for the development of cardiovascular diseases $[9,25]$

Regarding the practice of physical activity, almost $70 \%$ of those evaluated were classified as sedentary. It happens that in the WSUs, most of the activities are repetitive with a low expenditure of energy. In other studies, the associations of waste pickers evidenced risks to ergonomy, characterized by intense physical effort, lifting weight manually, inadequate postures, excessive work rhythm, posture at work and physical and psychological stress [41] .

It should be highlighted that psychoactive substances, such as tobacco, alcohol and marijuana were used by many of the study subjects. Many family members work together at these associations, and it is inferred that the younger members begin to use substances while they work, as they see their peers using them, reinforcing the behavior of use. In another study, it was found that as new work morphologies were intensified, there was an increase in the classifications of job insecurity. This contributed to work activity related distress [42]. Seligmann-Silva (2011) states that work, depending on the situation, may strengthen mental health or render it vulnerable, and even develop disorders that will be expressed at social and individual levels, "such as the use of alcohol and other drugs"[43].

A positive relation between the high BMI indices and the use of alcohol was observed. This may be associated with the fact that alcohol is a source of calories and acts by deregulating other metabolic pathways, including by diminishing lipid oxidation, leading to a positive balance of fats, especially in the abdominal region $[44,45]$.

A few aspects were limiting factors in the study, such as the great turnover of associates within the units, which makes it difficult to follow it longitudinally and made new data collections impossible. Another aspect was the difficulty for recyclers to interrupt work activity to participate in the survey, since there was an economic implication (they earn proportionally to what they recycle, they tend to take less breaks in order to earn more). Although these factors made it difficult to implement, they did not prove to be a major obstacle, since most of the pickers accepted to participate in the study, representing $77 \%$ of the workers from the units evaluated. In spite of that, there's still a need for work to promote health promotion awareness in their workplaces and further sensitization aiming to increase the visibility of the picker population.

\section{Conclusion}

Recyclers contribute to the recycling market and to the environment, despite precarious conditions, low income, contact with hazardous material, high risk of occupational accidents or disease, without occupational rights and without due acknowledgment from society or from public administrators. 
The results of this study show the need for interdisciplinary health interventions in this population, both in the field of nutrition and in multidisciplinary health, in order to prevent work related risks, and also the risk of the development of cardiovascular diseases resulting from food insecurity and obesity. The articulation between intersectoral arrangements, communities and the implementation of public policies to address the population studied also should be considered in later discussion .

In the future it would be useful to study and explore other issues related to health problems in this population, such as housing conditions, quality of the food found in their homes, and the possibility of incorporating educational actions to promote health in the work environment.

\section{Abbreviations}

ASSIST: Alcohol, Smoking and Substance Involvement Screening Test; BMI: Body Mass Index; EBIA: Brazilian Scale of Food Insecurity; HCPA: Hospital de Clínicas de Porto Alegre; IPAQ; Physical Activity Questionnaire; SPSS: Statistical Package for the Social Sciences; USDA: United States Department of Agriculture; WC: Waist Circumference; WHO: World Health Organization; WSU: Waste Sorting Units.

\section{Declarations}

Acknowledgements

We would like to thank all the data collection team members, the recyclers who participated in this study, and Porto Alegre's Health Department. We also would like to thank all members from the Graduate Program in Gastroenterology and Hepatology from UFRGS.

\section{Funding}

This study was supported by a grant from CAPES and FIPE/HCPA. The funding sources were not involved in the study design; in the collection, analysis and interpretation of data; in the writing of the report; or in the decision to submit the paper for publication.

Availability of data and materialsData used for this study can be accessed upon request from the Principal Investigator (Ms. Cássia Medino Soares) at cassia.medino.cs@gmail.com

Authors' contributions

CMS planned and wrote the project, collected and analyzed the data regarding food insecurity, wrote the final manuscript. CS collected and analyzed the anthropometric data, wrote and participated in the critical review of the manuscript. BCA collected and analyzed the fisical anthropometric data, wrote and participated in the critical review of the manuscript. CBB collected data regarding physical activity, wrote and participated in the critical review of the manuscript. PRTSF co-wrote the project, collected data regarding substance abuse, performed most of the statistical analysis and wrote the manuscript. DJ planned and co-wrote the project, co-wrote the final manuscript and reviewed all steps.VDA planned and 
co-wrote the project, co-wrote the final manuscript and reviewed all steps. All authors read and approved the final manuscript.

Authors' Information

CMS, CS, BCA and CBB are Nutritionists from the Graduate Program in Gastroenterology and Hepatology at Federal University of Rio Grande do Sul (UFRGS) in Porto Alegre, Brazil. PRTSF is a psychologist from the graduate program in Health Psychology at the Federal University of Health Sciences from Porto Alegre (UFCSPA) in Porto Alegre, Brazil. DJ and VDA are professors at the Clinical Hospital of Porto Alegre (HCPA) and at the Graduate Program in Gastroenterology and Hepatology at Federal University of Rio Grande do Sul (UFRGS) in Porto Alegre, Brazil.

Ethics approval and consent to participate

This study was approved by the The Health Ethics Committee for Hospital de Clínicas de Porto Alegre (HCPA) linked to the Ministry of Health and Ministry of Education, (No. 2.162.481). A written informed consent was obtained from all participants.

Consent for publication

Not applicable.

Competing interests

The authors declare that they have no competing interests.

\section{References}

1. Food and Agriculture Organization of the United Nations. The state of food insecurity in the world, 2001. Rome: FAO;2001. Available from: http://www.fao.org/3/y1500e/y1500e00.htm Accessed Jun 2018.

2. Reis M. Food insecurity and the relationship between household income and children's health and nutrition in Brazil. Health Econ. 2012; 21(4):405-27.

3. Casey PH, Simpson PM, Gossett JM, Bogle ML, Champagne CM, Connell C, Harsha D, McCabe-Sellers B, Robbins JM, Stuff JE, Weber J. The association of child and household food insecurity with childhood overweight status. Pediatrics. 2006; 118(5):e1406-13.

4. Pérez et al. Food insecurity and self-rated health in rural Nicaraguan women of reproductive age: a cross-sectional study. International Journal for Equity in Health. 2018;17:146.

5. Jones AD, Ngure FM, Pelto G, Young SL. What are we assessing when we measure food security? A compendium and review of current metrics. Adv Nutr. 2013;1;4(5):481-505. 
6. FAO, IFAD, UNICEF W and W. The state of food security and nutrition in the world 2017. Building resilience for peace and food security. Rome: FAO; 2017. Available from: http://www.fao.org/3/a17695e.pdf. Accessed Jun 2018.

7. FAO, IFAD and WFP. The State of Food Insecurity in the World 2014. Strengthening the enabling environment for food security and nutrition. Rome: FAO; 2014. Available from: http://www.fao.org/3/ai4030e.pdf Accessed May 2018.

8. Cavalcante S, Franco MFA. Profissão perigo: percepção de risco à saúde entre os catadores do Lixão do Jangurussu. Rev. Mal-Estar Subj. 2007;7 (1): 211-231.

9. Teichmann L, Olinto MTA, Costa JSD, Ziegler D. Fatores de risco associados ao sobrepeso e a obesidade em mulheres de São Leopoldo, RS. Rev. bras. Epidemiol., 2006; 9 (3): 360-373.

10. Burity V, Franceschini $T$, Valente $F$, Recine $E$, Leão $M$, Carvalho MF. Direito humano à alimentação adequada no contexto da segurança alimentar e nutricional. ABRANDH. Brasília, DF: 2013.

11. Bezerra TA, Olinda RA, Pedraza DF. Food insecurity in Brazil in accordance with different sociodemographic scenarios. Ciência \& Saúde Coletiva, 22(2):637-651, 2017.

12. Conselho Nacional de Segurança Alimentar e Nutricional. A Segurança Alimentar e Nutricional e o direito humano à alimentação adequada no Brasil. CONSEA. Brasília, DF: 2010.

13. Instituto Brasileiro de Geografia e Estatística - IBGE. Pesquisa Nacional de Saneamento Básico 2008. Rio de Janeiro, RJ: 2010.

14. Soler F, Silva Filho CR. Gestão de Resíduos Sólidos. 4rd ed. Trevisan Editora: São Paulo; 2019.

15. Grayley MY. ONU diz que mundo sofre ameaça de crise global de lixos urbanos. 2012. Available from: http://www.unmultimedia.org/radio/portuguese/2012/11/onu-diz-que-mundosofre-ameaca-de-criseglobal-de-lixos-urbanos/ Accessed: 26 Nov. 2016.

16. Brasil. Lei $n^{\circ} 12.305$, de 2 de agosto de 2010. 2010. Available from: http://www.planalto.gov.br/ccivil_03/_ato2007-2010/2010/lei//12305.htm Accessed: 10 Nov. 2016.

17. Laurell AC, Noriega M. Processos de produção e saúde: Trabalho e desgaste operário. São Paulo: Ática; 1989.

18. Ferreira JA, Anjos LA. Aspectos de saúde coletiva e ocupacional associados à gestão dos resíduos sólidos municipais. Cad. Saúde Pública. 2001; 17 (3), 689-696.

19. Porto MFS, Juncá DCM, Gonçalves RS, Filhote MIF. Lixo, trabalho e saúde: um estudo de caso com catadores em um aterro metropolitano no Rio de Janeiro, Brasil. Cad. Saúde Pública. 2004; 20 (6):15031514. 
20. Instituto Brasileiro de Geografia e Estatísticas (IBGE). Pesquisa Nacional por Amostra de Domicílios (PNAD). Segurança Alimentar: 2013. Rio de Janeiro: IBGE; 2014.

21. Recicla POA. 2017. Available from: http://www.reciclaportoalegre.com.br/ Accessed 10 May 2018.

22. Perez Escamilla R, Segall Correa AM, Kurdian Maranha L, Sampaio MMF, Marin-Leon L, Panigassi G. An adapted version of the U.S. Department of Agriculture Food Insecurity module is a valid tool for assessing household food insecurity in Campinas, Brazil. J Nutr 2004; 134:1923-8.

23. Matsudo $S$ et al. Questionário internacional de atividade física (IPAQ): estudo de validade e reprodutibilidade no brasil. Atividade Física e Saúde. 2001; 6 (2).

24. Henrique IFS et al. Validação da versão brasileira do teste de triagem do envolvimento com álcool, cigarro e outras substâncias (ASSIST). Rev Assoc Med Bras. 2004; 50(2): 199-206.

25. WHO. Obesity: preventing and managing the global epidemic. Report of a WHO Consultation. WHO Technical Report Series 894. Geneva: World Health Organization, 2000.

26. Lipschitz DA. Screening for nutritional status in the elderly. Prim Care. 1994;21(1):55-67.

27. Almeida et al. Factors associated with food insecurity risk and nutrition in rural settlements of families. Ciênc. saúde colet. 2017; 22 (2).

28. United States Department of Agriculture. Understanding the Prevalence, Severity, and Distribution of Food Insecurity in the United State. United States: USDA, 2016. Available from:

https://www.ers.usda.gov/amber-waves/2017/september/understanding-the-prevalence-severity-anddistribution-of-food-insecurity-in-the-united-states/ Accessed 10 Jun 2018.

29. Alderete $E$ et al. Emerging themes in food security: environmental justice, extended families and the multiple roles of grandmothers. International Journal for Equity in Health. 2018;17:139.

30. Coleman Jensen A, Rabbitt MP, Gregory CA, Singh A. Household Food Security in the United States in 2015, ERR-215, U.S. Department of Agriculture, Economic Research Service, September 2016. Available from: https://www.ers.usda.gov/webdocs/publications/79761/err-215.pdf Accessed 17 Mar 2017.

31. Weigel MM, Armijos RX, Racines M, Cevallos W. Food Insecurity Is Associated with Undernutrition but Not Overnutrition in Ecuadorian Women from Low-Income Urban Neighborhoods. Journal of Environmental and Public Health. 2016; 2016:15.

32. FAO. Methods for estimating comparable rates of food insecurity experienced by adults throughout the world. Rome, FAO, 2016. Available from: http://www.fao.org/3/c-i4830e.pdf Accessed 11 Mar 2017.

33. Brasil. Ministério da Saúde (MS). Pesquisa Nacional de Demografia e Saúde da Criança e da Mulher. Brasília: MS. 2008. Available from: http://bvsms.saude.gov.br/bvs/publicacoes/relatorio_pnds_2006.pdf 
Accessed 09 Mar 2017.

34. Marin Leon L. et al. Household appliances and food insecurity: gender, referred skin color and socioeconomic differences Rev Bras Epidemiol. 2011; 14(3): 398-410.

35 Alves BT, Alves OR, Figueroa PD. Food insecurity in Brazil in accordance with different sociodemographic scenarios. Ciênc. saúde coletiva. 2017. 22(2): 637-651.

36. ABESO - Associação Brasileira para o Estudo da Obesidade e da Síndrome Metabólica. - 3.ed. Itapevi, SP: AC Farmacêutica, 2009.

37. Oliveira JEP, Montenegro RM, Vencio S. Diretrizes da Sociedade Brasileira de Diabetes 2017-2018. São Paulo: Editora Clannad, 2017.

38. Caballero B. The global epidemic of obesity: an overview. Epidemiol Rev. 2007; 29:1-5.

39. Albuquerque MFM. A segurança alimentar e nutricional e o uso da abordagem de direitos humanos no desenho das políticas públicas para combater a fome e a pobreza. Revista Nutrição, Campinas. 2009; 22 (6): 895-903.

40. Gutierrez FJL, Regidor E, Banegas JRB, Artalejo FR. The size of obesity differences associated with educational level in Spain, 1987-1995/97. J pidemiol Community Health. 2002; 56(6): 457-60.

41. Pesquisa nacional de saúde: acesso e utilização dos serviços de saúde, acidentes e violências: Brasil, grandes regiões e unidades da federação/IBGE, Coordenação de Trabalho e Rendimento. - Rio de Janeiro: IBGE, 2015.

42. Dejours C. A banalização da injustiça social. Rio de Janeiro: Editora FGV, 2007.

43. Seligmann S. Trabalho e desgaste mental: o direito de ser dono de si mesmo. Editora São Paulo: Cortez, 2011.

44. Kachani, A.T. et al. The impact of alcohol consumption on weight gain. Rev. Psiq. Clín. 2008; 35 (1); 21-24.

45. Suter PM. Is alcohol consumption a risk factor for weight gain and obesity? Crit Revista Clin Lab Science. 2005; 42 (3);197-227.

46. Schmeer KK, Piperata BA, Herrera Rodríguez A, Salazar Torres VM, Centeno Cárdenas FJ. Maternal resources and household food security: evidence from Nicaragua. Public Health Nutr. 2015; 18(16):291524.

47. Pillaca S, Villanueva M. Evaluación de la seguridad alimentaria y nutricional en familias del distrito de los morochucos en Ayacucho, Perú. Rev. perú. med. exp. salud publica. 2015; 32 (1): 73-79. 


\section{Manuscript Tables}

Due to technical limitations, Manuscript Tables 1 and 2 are only available as downloads in the supplemental files section.

\section{Supplementary Files}

This is a list of supplementary files associated with this preprint. Click to download.

- ManuscriptTable2.jpg

- Figure1.pdf

- ManuscriptTable1.jpg

- Table2.xml

- Table1.xml 